\title{
PEMANFAATAN AUGMENTED REALITY DALAM MEMVISUALISASIKAN PRODUK PERUMAHAN MELALUI INTERNET
}

\author{
Bonny A Suryawinata \\ Jurusan Arsitektur, Fakultas sains dan teknologi, Universitas Bina Nusantara, \\ Jln. K.H. Syahdan No. 9, Kemanggisan, Palmerah, Jakarta Barat 11480 \\ bonnys@binus.edu
}

\begin{abstract}
To attract house buyers, many ways is done by the developers to promote their products, such as by using multiple marketing medias namely television, radio, internet, newspapers or distribute flyers during the exhibition. It is not uncommon that the said use of multiple media elements still make prospective buyers feel confused, because they can not imagine the shape of the house, since all they see is a flat two dimensional (2D) object. To obtain detailed product information house of course they have to visit the exhibition or housing sales office that would spend the time and cost. This is why the authors proposed an application that can display $3 D$ images over the Internet by using Augmented Reality technology, so that prospective home buyers can access these applications anytime and anywhere.
\end{abstract}

Keywords: housing, promotion, augmented reality

\begin{abstract}
ABSTRAK
Untuk menarik minat pembeli produk perumahan, banyak cara yang dilakukan oleh para developer untuk mempromosikan produknya, diantaranya adalah dengan menggunakan beberapa media pemasaran seperti tv, radio, internet, koran atau menyebarkan brosur pada saat pameran. Penggunaan beberapa elemen media tersebut tidak jarang masih membuat calon pembeli merasa bingung, karena mereka belum bisa membayangkan bentuk rumahnya seperti apa, sebab obyek yang mereka lihat adalah obyek dua dimensi (2D) yang terlihat datar. Untuk mendapatkan informasi produk rumah secara detail tentunya mereka juga harus mendatangi kantor pemasaran atau pameran perumahan yang akan menghabiskan waktu dan biaya. Hal inilah yang mendasari penulis untuk mengusulkan sebuah aplikasi yang dapat menampilkan gambar 3D melalui internet dengan memanfaatkan teknologi Augmented Reality, sehingga calon pembeli rumah dapat mengakses aplikasi ini kapan saja dan dimana saja.
\end{abstract}

Keywords: perumahan, promosi, augmented reality 


\section{PENDAHULUAN}

Saat ini di dalam dunia teknologi informasi telah berkembang sebuah teknologi dengan apa yang disebut Augmented Reality. Augmented Reality (AR) atau aplikasi realitas yang diperluas, dapat membuat pengguna (user) melihat tampilan obyek secara tiga dimensi (3D) bahkan dapat berinteraksi dengan obyek tersebut. Hal ini tentunya membuat pengguna semakin terhibur menikmati teknologi sekaligus memperoleh informasi konten yang dibutuhkan. Sebut saja Kompas, salah satu media informasi terbesar di tanah air telah menggunakan teknologi ini untuk menarik minat pembacanya. Kini pembaca Kompas dapat melihat 3D motion dan video, hanya dengan meletakkan foto berita di depan webcam, 3D interaktif dan video pun langsung muncul di layar komputer.

Dengan memanfaatkan teknologi AR pada bidang perumahan tentunya juga akan menarik minat pembeli. Mereka tidak perlu datang ke pameran perumahan atau ke kantor pemasaran untuk melihat produk rumah yang akan dibeli, cukup duduk di depan komputer rumah lalu berinterkasi dengan model rumah secara 3D melalui internet. Tidak hanya pembeli dapat melihat bagian dalam rumah dengan detil, tetapi lingkungan disekitar rumah juga akan terasa lebih hidup dengan adanya animasi pendukung seperti mobil yang melintas, burung-burung terbang dan lain sebagainya. Dengan demikian hal ini akan menjadi daya tarik calon pembeli untuk melihatnya.

\section{Augmented Reality}

Augmented Reality (AR) adalah kombinasi antara dunia maya (virtual) dan dunia nyata (real) yang dibuat oleh komputer. Objek virtual dapat berupa teks, animasi, model 3D atau video yang digabungkan dengan lingkungan sebenarnya sehingga pengguna merasakan objek virtual berada dilingkungannya. AR adalah cara baru dan menyenangkan dimana manusia berinteraksi dengan komputer, karena dapat membawa objek virtual ke lingkungan pengguna, memberikan pengalaman visualisasi yang alami dan menyenangkan. Sistem ini berbeda dengan Virtual Reality (VR), yang sepenuhnya merupakan virtual environment. Perbedaan AR dan VR seperti yang diperlihatkan pada grafik Milgram Continuum (Gambar 1).

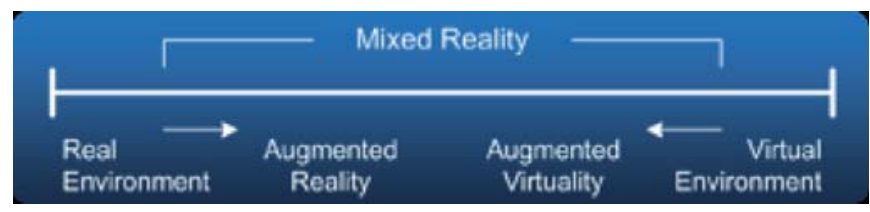

Gambar 1 - Grafik Milgram Continuum

Dengan bantuan teknologi AR lingkungan nyata disekitar kita akan dapat berinteraksi dalam bentuk digital (virtual). Informasi informasi tentang objek dan lingkungan disekitar kita dapat ditambahkan kedalam sistem AR yang kemudian informasi tersebut ditampilkan diatas layer dunia nyata secara real-time seolah-olah informasi tersebut adalah nyata.

Tantangan utama dari sistem AR adalah bagaimana menggabungkan dunia maya dan dunia nyata ke sebuah lingkungan tunggal. Untuk menjaga ilusi pengguna terhadap objek virtual yang seolah-olah bagian dari dunia nyata memerlukan registrasi konsisten dari dunia maya dengan dunia nyata. Hal dasar yang menjadi masalah registrasi di dalam sistem AR seperti terlihat pada Gambar 2 dimana gambar virtual menambah dua pandangan bagian atas layar. Untuk menciptakan lingkungan AR yang akurat dinyatakan dalam bentuk hubungan yang harus ditentukan. Hubungan ini antara lain object-to-world, $O$, world-to-camera, $C$, dan camera-to-image plane, $P$, transforms 


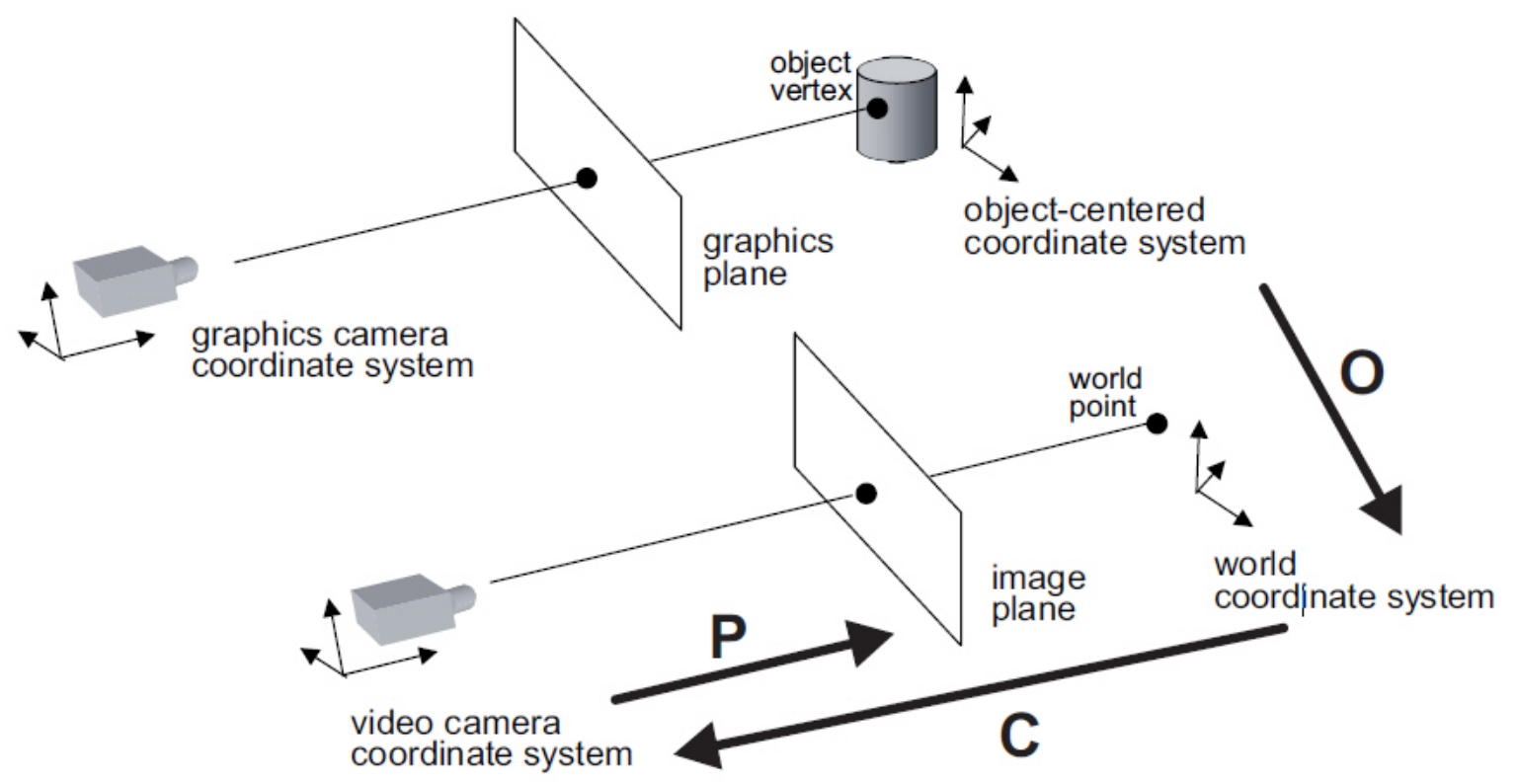

Gambar 2 - Sistem koordinat AR

Perubahan bentuk object-to-world menentukan posisi dan orientasi objek virtual dengan mengikuti sistem world coordinate yang mendifinisikan adegan sebenarnya. Perubahan bentuk worldto-camera mendefinisikan pose dari kamera video yang menampilkan adegan sebenarnya. Perubahan bentuk camera-to-image plane menetapkan proyeksi kamera untuk menciptakan gambar 2D dari gambar scene 3D sebenarnya. Untuk menciptakan sebuah gambar objek virtual tiga dimensional sesuai dengan pandangan pengguna yang sebenarnya dan penempatan objek di dalam dunia nyata membutuhkan definisi hubungan geometrik antara virtual dan objek fisik seperti pada Gambar 2.

\section{Hardware dan Software}

Seperti teknologi komputer pada umumnya terbagi atas Perangkat Keras (Hardware) dan Perangkat Lunak (Software). Hardware utama AR antara lain, display, marker, input device dan komputer. Bahkan saat ini smartphone telah menjadi perangkat andalan yang digunakan untuk mengembangkan AR.

\section{Display}

Display adalah perangkat keras untuk menampilkan AR ke objek nyata. Ada beberapa teknik utama display AR, antar lain:

1. Head Mounted Display (HMD)

Pada Gambar 3 kita dapat melihat sebuah bangunan dan sebuah hologram konstruksi yang diciptakan oleh komputer melapisi bangunan sehingga terlihat sebagai satu kesatuan. Seperti inilah AR bekerja menggunakan HMD pada awal pengembangannya. 



Gambar 3 - Kombinasi objek virtual dan lingkungan sebenarnya menggunakan AR

HMD menempatkan gambar dunia nyata dan gambar virtual sehingga pengguna dapat melihat seolah olah gambar virtual tersebut berada di dunia nyata. HMD baik itu optical see-through atau video seethrough dapat menyatu dengan alam. Sebuah optik tembus menggunakan teknologi halfsilver mirror memungkinkan pandangan dunia fisik melewati lensa dan informasi overlay grafis akan tercermin ke mata pengguna.



Gambar 4 - HMD optical see-through 
HMD harus dilacak menggunakan enam derajat pelacakan sensor. Hal ini memungkinkan sistem komputasi untuk meregistrasi informasi virtual ke dunia fisik. Keuntungan utama dari HMD AR adalah pengalaman mendalam bagi pengguna. Informasi grafis bekerja keras untuk pandangan pengguna

\section{Magic Mirror display}

Magic mirror terdiri atas monitor komputer, televisi atau proyektor dibelakang lingkungan yang akan ditangkap oleh kamera AR. Display adalah mirror atau gabungan gambar dari sistem AR dan akan menampilkan gambar secara menerus melaui video secara realtime.

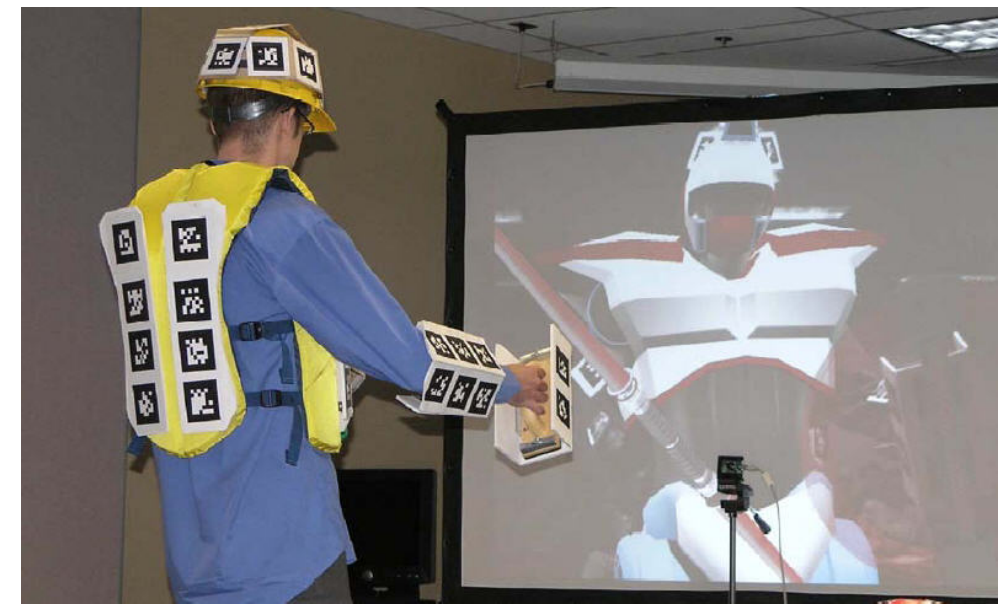

Gambar 5 - Magic Mirror display

3. Magic Lens Display dan Handheld Display

Magic lens display sangat berbeda dengan magic mirror. Magic mirror seperti halnya orang yang sedang berkaca di depan cermin, sedangkan magic lens membuat image virtual yang kita lihat seolah-olah berada di dunia nyata.

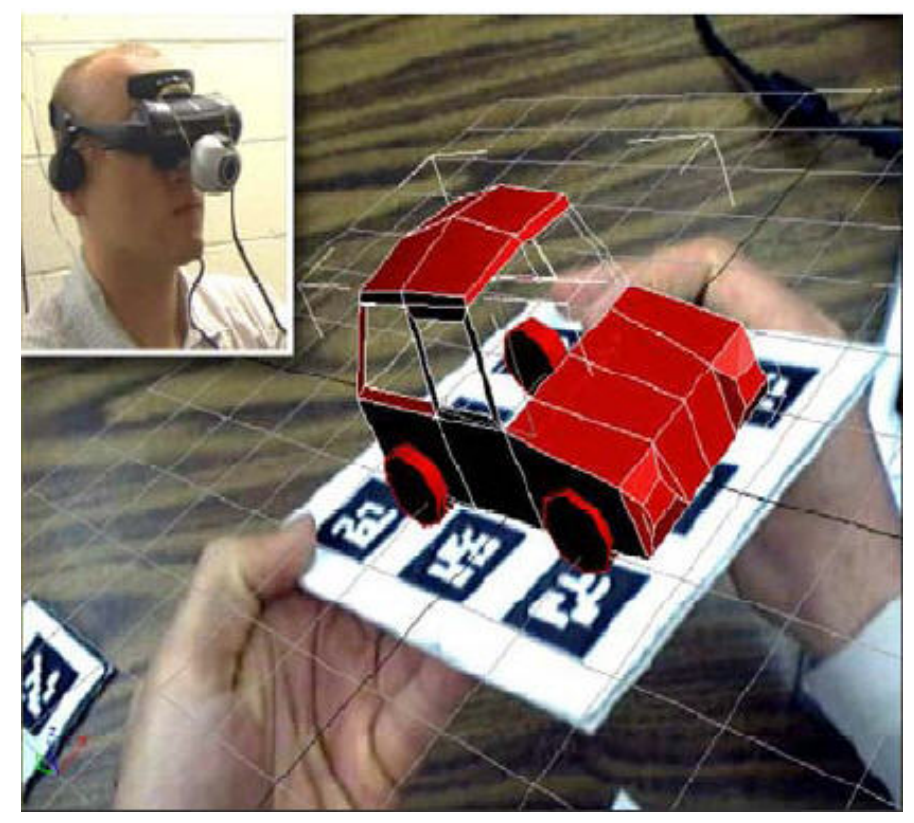

Gambar 6 - Magic Lens Display 
Handheld AR menjalankan perangkat komputasi kecil dengan tampilan yang pas di tangan pengguna. Semua handheld AR sampai saat ini telah menggunakan teknik seethrough video untuk meng-overlay informasi grafis ke dunia fisik. Awalnya handheld AR bekerja seperti kompas digital dan digunakan pula unit GPS pelacakan sensor.

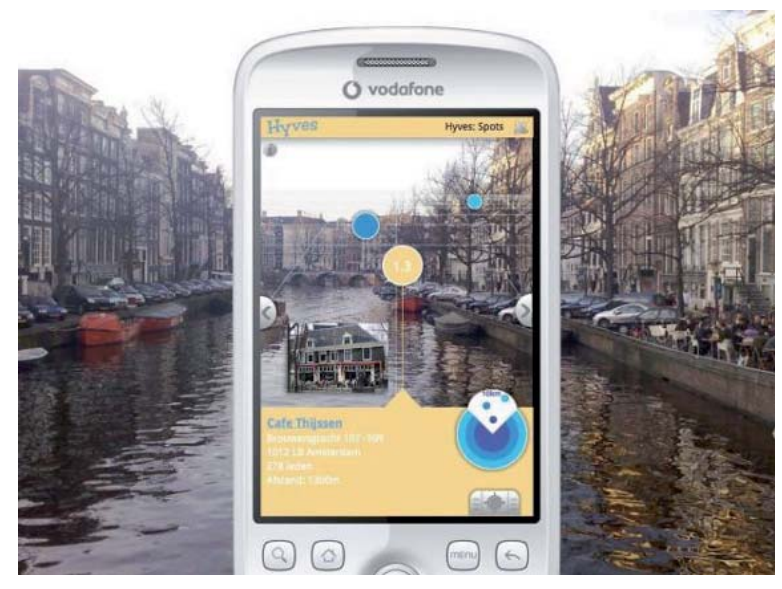

Gambar 7 - Handheld Display

Saat ini telah banyak telepon selular (ponsel) berkamera yang dapat menggunakan tekonologi AR ini. Objek nyata akan ditangkap oleh kamera ponsel dan virtual objek akan digabungkan ke layar ponsel. Di Amerika Serikat sekarang sudah banyak yang menggunakan teknologi ini untuk melihat informasi yang ada di sekitarnya, dengan menggunakan iPhone atau iPhod kita dapat melihat informasi di sekililing kita melai aplikasi Bionic Eye.

\section{Monitor Based Display}

Cara kerja sistem ini adalah seperti pada Gambar 8, pertama kamera menangkap gambar lingkungan nyata melalui video secara real-time, kemudian aplikasi mencari dan mencocokkan pola pada video dengan pola yang ada pada aplikasi, setelah itu aplikasi mengukur besar dan jarak pola, kemudian menaruh lapisan gambar dengan ukuran yang sama pada pola dan setelah itu aplikasi merender objek 3D pada lapisan tersebut.




Sistem inilah yang penulis usulkan untuk dikembangkan aplikasinya. Karena tidak memerlukan biaya yang besar untuk pengembangannya.

\section{Webcam}

Webcam adalah kamera digital yang terhubung dengan komputer, baik langsung maupun melalui wireless dan menangkap serangkaian gambar-gambar atau video secara langsung. Webcam sudah menjadi teknologi yang umum digunakan. Banyak orang sudah menggunakan alat ini untuk keperluan mereka.

\section{FIARToolKit}

FLARToolKit adalah aplikasi non komersial dibawah lisensi GNU. Aplikasi ini berbasis ActionScript 3 dari Adobe Flash. Dengan aplikasi ini programer dengan mudah mengembangkan aplikasi AR sesuai keinginan mereka. FLARToolKit adalah aplikasi multi platform yang dapat berjalan di sistem operasi Windows, Mac OS dan Linux. Hal tersebut yang menjadi dasar mengapa para developer IT di seluruh dunia banyak menggunakan aplikasi ini. Pemilihan FLARToolKit juga didasarkan karena aplikasi ini akan menjadi format shockwave file flash (.swf), yang sudah menjadi aplikasi umum di dunia web. Dan bahkan saat ini beberapa ponsel sudah memiliki aplikasi ini.

\section{Papervision 3D}

Papervision3D (PV3D) adalah aplikasi open source engine 3D untuk Flash yang cukup populer. Dengan aplikasi ini para AR developer dapat membuat objek secara tiga dimensional untuk ditampilkan melalui browser web atau Flash Player. Dibandingkan dengan engine 3D lainnya seperti away3D dan Flash3D, aplikasi PV3D lebih mudah digunakan. Itu sebabnya banyak AR developer menggunakan aplikasi ini.

\section{Actionscript 3}

Actionscript 3 (AS3) adalah merupakan bahasa pemograman Object Oriented Programming (OOP) yang dapat dijalankan melalui Flash Player. Penggunaan AS3 sangat cocok untuk pengembangan aplikasi internet, atau lebih dikenal dengan Rich Internet Application, dan bahasa pemograman ini sudah menjadi bagian dari dunia web. Banyak developer game dan flash designer menggunakan Actionscript, karena bahasa pemograman ini mudah digunakan. Sebagian besar aplikasi flash yang ada di web semuanya menggunakan Actionscript.

\section{Adobe Flex Builder}

Flex adalah actionscript compiler yang dibuat oleh Adobe. Software ini dikembangkan berdasarkan Eclipse IDE. Software ini sangat efisien dan produktif, karena layout desain yang baik, dapat melakukan step-through debuggin, dan juga memiliki kemampuan code refactoring.

\section{Fiducial Marker}

Fiducial marker adalah sebuah penanda yang didalamnya terdiri dari kumpulan titik acuan untuk memudahkan komputasi dari pengukuran parameter-parameter yang dibutuhkan dalam pengolahan citra. Marker dapat berupa warna atau dapat berupa gambar. Sudah banyak penelitian tentang penanda untuk keperluan AR. Penanda yang paling sederhana dan bekerja dengan sangat baik adalah penanda Matrix. Penanda matrix menggunakan 2D barcode sederhana, yang dipakai untuk mengenali sebuah objek dan untuk mengetahui hubungan antara posisi kamera dengan penanda tersebut. 




Gambar 9 - Fiducial Marker

Marker ini akan dikenali oleh FLARToolKit melalui kamera video. Marker ini juga digunakan untuk memberikan posisi objek 3D yang dijalankan oleh aplikasi AR.

\section{Internet}

Secara harfiah, internet (kependekan dari interconnected-networking) ialah rangkaian komputer yang terhubung di dalam beberapa rangkaian. Manakala Internet (huruf 'I' besar) ialah sistem komputer umum, yang berhubung secara global dan menggunakan TCP/IP sebagai protokol pertukaran paket (packet switching communication protocol). Rangkaian internet yang terbesar dinamakan Internet. Cara menghubungkan rangkaian dengan kaedah ini dinamakan internetworking.

\section{HASIL DAN PEMBAHASAN}

Aplikasi nantinya yang akan dibuat adalah seperti aplikasi AR yang telah dikembangkan oleh media Kompas. Aplikassi ini bertujuan untuk memaksimalkan informasi media pemasaran produk rumah dari media 2D menjadi tampilan 3D multimedia yang menarik, dan membantu para pembeli untuk mengetahui dengan baik rumah yang akan mereka beli melalui internet sehingga tentunya akan membantu meningkatkan penjualan rumah.

\section{Diagram Konteks}

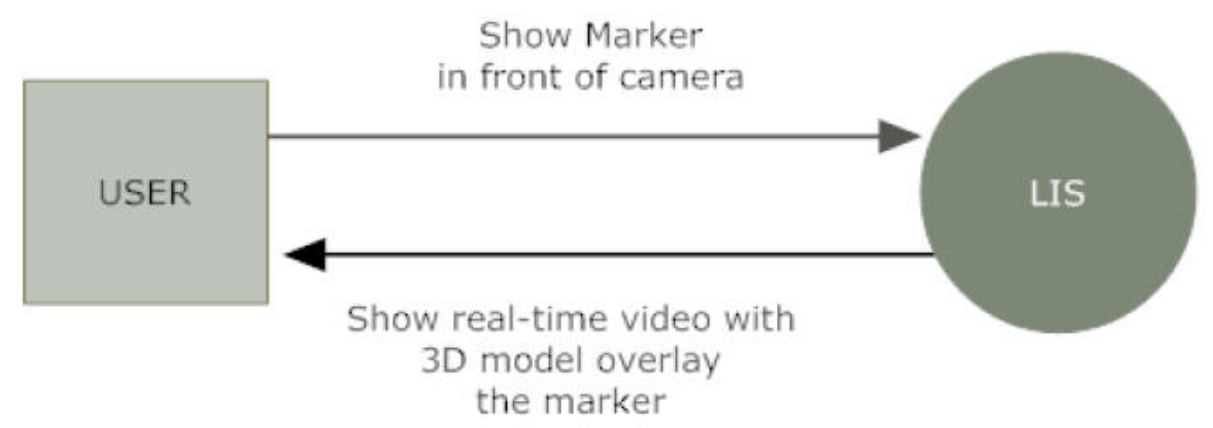

Gambar 10 - Diagram Konteks

Ketika aplikasi dijalankan akan terlihat lingkungan nyata yang ditangkap oleh webcam. Webcam ini bekerja sebagai pengenal pola. Ketika pengguna meletakan kertas marker pada webcam maka model rumah 3D akan muncul pada layar monitor tepat di atas kertas marker tadi. 


\section{Diagram Alur}

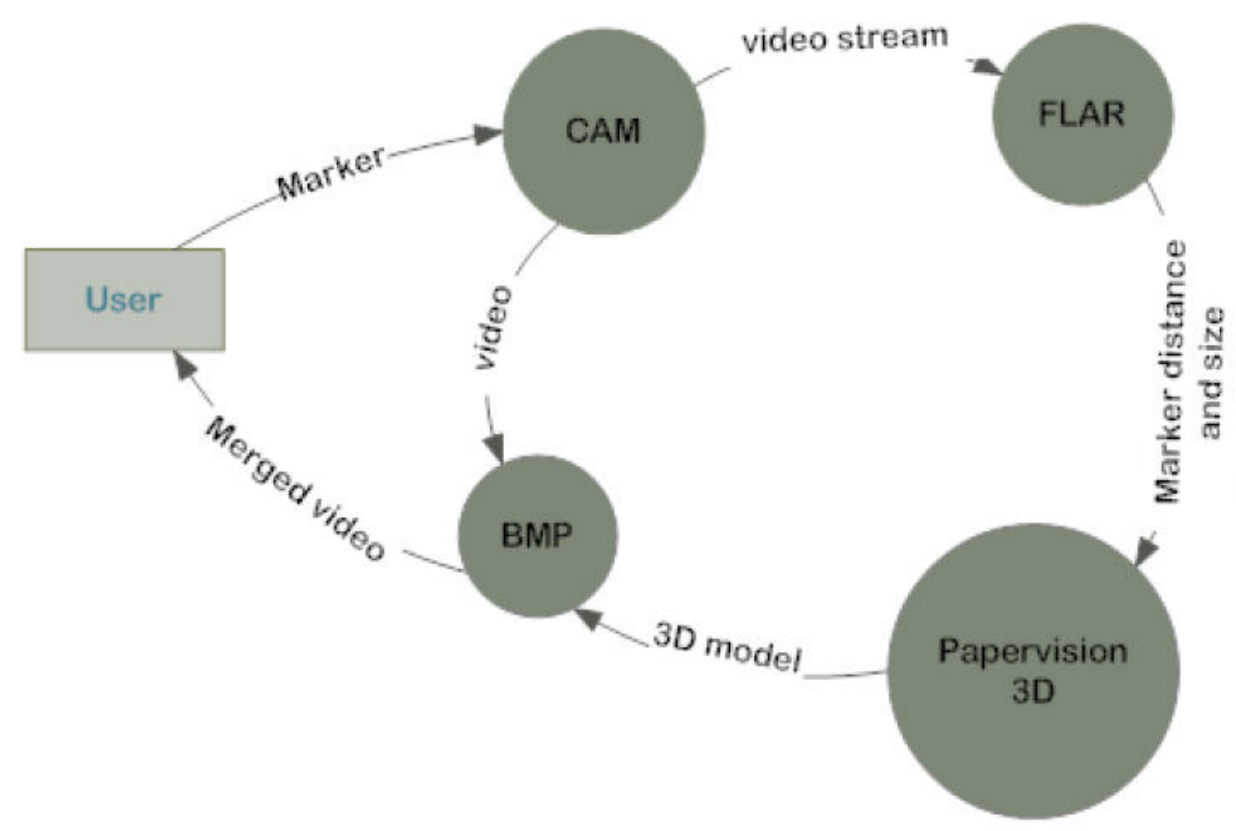

Gambar 11- Diagram Alur

Seperti terlihat pada gambar diagram di atas, ada 4 komponen untuk aplikasi ini. Pertama adalah CAM yang berfungsi untuk menangkap lingkungan nyata dari webcam peengguna, dan juga membuat lapisan gambar baru untuk diletakan pada objek virtual yang akan dibuat oleh sistem. Kedua adalah komponen FLAR yang berfungsi untuk mengenali marker di dalam gambar yang dikirim oleh CAM melalui pola yang cocok dan juga mengukur jarak dan ukuran dari marker dan kemudian mengirim hasilnya kepada komponen lain. Ketiga adalah komponen Papervision, yang akan mengambil jarak dan ukuran marker dari FLAR dan merender model 3D yang telah ditentukan untuk marker berdasarkan ukuran dan jarak dari FLAR. Dan yang terakhir adalah BMP yang menciptakan sebuah lapisan gambar untuk mengisi hasil render model 3D dan menaruhnya di atas marker, dan mengkombinasikannya dengan gambar dari CAM, kemudian mengirim gabungan gambar tersebut kepada pengguna secar real time.

\section{Model 3D}

Model rumah 3D yang digunakan didesain dengan menggunakan perangkat lunak Autocad 2010 dan 3D Max 2010. Hal pertama yang dilakukan adalah mengkonversi file Autocad yang berformat .dwg ke dalam format file 3D Max. Setelah diolah dalam file 3D Max, file kemudian di konversi menjadi format COLADA (.dae).

\section{Class Diagram.}

Ada dua engine utama yang digunakan untuk aplikasi ini, yaitu FLARToolKit dan Papervision3D (PV3D). Engine-engine mudah diperoleh melalui internet dan dberikan secara gratis. FLARToolKit memuat banyak class dengan funtion yang berbeda-beda. Untuk aplikasi ini nantinya hanya menggunakan 5 class. Fungsi utama FLARToolKit adalah mendeteksi marker dan menambahkan gambar virtual ke video. Class pertama adalah FLARParams, fungsi class ini membuat parameter dan mengambil parameter dari webcam. Kedua adalah class FLARCode untuk membuat marker dan memuat pola dari aplikasi. Ketiga adalah FLARSingleMarkerDetector yaitu class untuk mendetkesi marker yang di load oleh FLARCode dari video stream webcam dan juga berfungsi 
mengukur jarak, ukuran dan distorsi dari marker. Keempat FLARCamera3D yang berfungsi untuk menambahkan kamera 3D untuk model 3D yang akan dimasukkan ke dalan aplikasi. Kamera 3D akan mencocokan distorsi dan ukuran marker yang yang tedeteksi yang kemudian mengambil parameter marker dari FLARParams. Kelima adalah FLARBaseNode yang akan membuat kontainer objek 3D dari aplikasi.

Seperti halnya FLARToolKit, PV3D juga memiliki banyak class, tapi penulis hanya menggunakan beberapa saja. Pertama adalah class Scene3D, yang berfungsi untuk membuat sebuah scene dimana seluruh objek-objek di render pada kontainer yang sama. Scene ditempatkan dimana objek ditempatkan, scene tersebut memuat informasi lingkungan 3D. Kedua adalah Viewport3D, yang digunakan untuk membuat sebuah viewport baru untuk aplikasi model 3D. Viewport ini menspesifikasikan dimana kita akan menggambar modl 3D di dalam virtual buffer. Ketiga adalah QuadrantRenderEngine, class ini untuk merender scene, viewport, dan FLARcamera3D dan model 3D sebenarnya yang ada di dalam aplikasi. Keempat adalah DAE class, digunakan untuk parse DAE ke dalam aplikasi. Kelima adalah class PointLight3D yang berfungsi untuk membuat cahaya dan bayangan pada objek.

Selain class-class yang telah disebutkan, aplikasi ini juga mengimport webcamera dan video class dari flash. Class ini berfungsi untuk mengambil akses webcam dan video stream untuk dimasukkan ke dalam aplikasi.

Class-class di atas digabung menjadi AugReal class yang kemudian menghasilkan gabungan tampilan lingkungan nyata dari webcam yang menyatu dengan model rumah 3D secara virtual.

\section{Implementasi Sistem}

Teknik AR yang digunakan untuk aplikasi ini adalah monitor based display.

Langkah-langkah yang dilakukan antara lain:

1. Membuka web browser



Gambar 12 - Tampilan aplikasi pada web browser

2. Mencetak marker ke printer, atau dapat pula menggunakan pola marker yang sudah tercetak pada media brosur atau media koran sebagai penanda. 

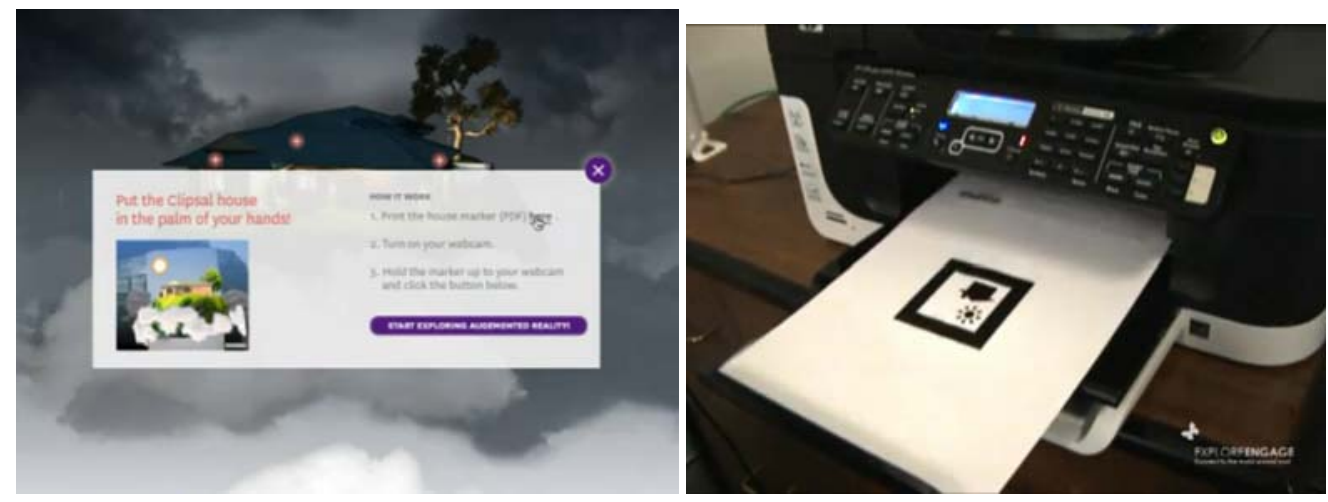

Gambar 13 - Mencetak marker

3. Kamera menangkap gambar lingkungan nyata melalui webcam secara real-time, kemudian aplikasi mencari dan mencocokkan pola marker pada video dengan pola marker yang ada pada aplikasi.

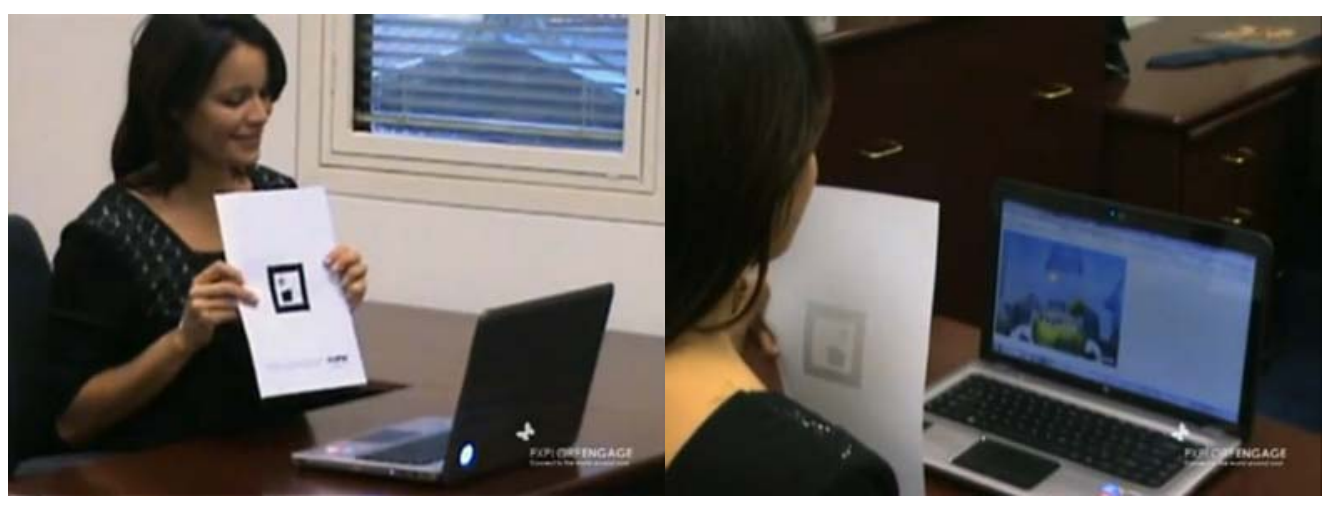

Gambar 14 - Mengarahkan marker ke webcam

4. Aplikasi merender objek 3D pada lapisan tersebut kemudian menampilkannya pada browser di web.


Gambar 15 - Tampilan gambar 3D multimedia pada web browser 


\section{SIMPULAN}

Dari banyak teknik utama untuk menampilkan AR, yang lebih cocok untuk diimplementasikan melalui internet adalah teknik Monitor Based Display. Karena tidak memerlukan biaya yang besar untuk pengembangannya.

Dengan mewujudkan aplikasi ini diharapkan akan dapat meningkatkan penjualan perumahan bagi para developer perumahan.

\section{DAFTAR PUSTAKA}

Liarokapis, F. (2009) Augmented Reality in Education (2003-2004). University of Sussex, Departement of Informatics, 2009

Rekimoto J., (1998) Matrix : A Real-Time Object Identification and Registration Method for Augmented Reality, Proceedings of the third Asia Pacific on computer-human interactions, Kangawa Japan, p. 63-98

Aliaga, D. G. (1994) Virtual and Real object Collisions in a Merged Environtment. Proceedings of VRST'94 (Singapore, 23-26 August 1994), 287-298, 1994 